\title{
RISK MANAGEMENT FOR START-UP COMPANY: A CASE STUDY OF HEALTHY KITCHEN RESTAURANT AND CATERING
}

\author{
Limbong Ruth Priskila \\ Esa Unggul University, Jakarta, Indonesia
}

\author{
Syah Tantri Yanuar R., Anindita Rina, Moelyono, Lecturers \\ Department of Management, Esa Unggul University, Jakarta, Indonesia
}

\author{
*E-mail: priskila.ruth@yahoo.com \\ ORCID: 0000-0003-3595-4835
}

\begin{abstract}
Entrepreneurs in the healthy food industry must pay attention to the risks of their business; i.e. in estimating and handling risks that will bring a direct or indirect negative impact on the healthy food business. The risks include risk of loss, risk of volatility, and risk of losing opportunities. Risk management is an approach chosen to understand, identify and evaluate risks that will later emerge. The research objective is to determine the risk management of the start-up company. The research findings showed that risk management is very important to conduct at each start-up restaurant of healthy food producer to avoid losses on costs, quality, and project schedules on the business operations, marketing, human resource, and financial aspects. The action response to the possibility of risk (risk response) is carried out through the retention risk, reduction risk, transfer risk, and avoidance risk. Risk assessment includes: identifying risks, understanding needs or considering risks, analyzing the impact of risks or evaluating risks, and being responsible for certain risks.
\end{abstract}

\section{KEY WORDS}

Risk, management, restaurant, project.

In carrying out production activities, internal and external sources need to be limited to achieving company goals and objectives (Sensebé et al., 2010). Therefore, companies need to analyze and carry out anticipatory activities to overcome these risks (Nasution, 2003).

Leaders, along with their working groups, also play an important role in overcoming risk management and controlling effective internal implementation (Fred, 2011). The company quantifies risk in each business unit by preparing short- and long-term goals. So, they set appropriate actions to reduce and minimize risk identification and monitor the implementation actions. The leader reviews and approves proposed actions to reduce the risks that have been identified.

Risk is generally defined as something negative; for instance, loss, danger, and other consequences. These losses are a form of uncertainty that can be studied and managed effectively by an organization as part of a strategy so that it becomes added value and support for organizational goals (Lokobal et. al., 2014).

Start-up restaurant is one of areas that have risks. Risks can have an impact on productivity, performance, quality and cost in a business. Risks can also be referred to as unexpected results. Although an activity is actually well planned, sometimes, it still has uncertainty.

Certainty is a situation that cannot be predicted beforehand. Every activity carried out by individuals or companies must have risks. Similarly, businesses also have risks. Large risks need to be taken into account with the receipt of the results of the business which will also be greater.

However, the risk of a startup restaurant of "Healthy Kitchen" cannot be avoided but can be reduced. If the risk will have an impact on project performance disruption, it can cause losses to the cost, time and quality of work. Entrepreneurs in the healthy food industry 
must pay attention to the risks of their business by estimating and handling risks that will bring a direct or indirect negative impact on the healthy food business. Those risks can lead to increased costs. Since it has a big impact, then research objective is to determine the risk management of the healthy-food restaurant.

\section{LITERATURE REVIEW}

Risks include risk of loss, risk of volatility, and risk of losing opportunities (Labombang, 2011). The management framework in an organization is directed at strategic, operational, reporting and compliance goals. Therefore, risk is a variation in things that may occur naturally or the possibility of threats to property and financial benefits caused by the existing dangers (Leonardus, 2009).

First, the strategic goal is to support the vision and mission of an organization. Second, the operational goal is the utilization of effectiveness and efficiency from the available sources. Third, the reporting goal is internal and external reports that can be trusted and relied upon. And fourth, the compliance goal is various laws and regulations of obedience.

Regarding activities in the restaurant sector, the occured activity process has involved related parties directly or indirectly. Operational risk may cause losses directly or indirectly such as the loss of the potential opportunity in a way to achieve it. In addition, operational risk can also cause losses that are difficult to calculate materially; for instance, damage to the restaurant's reputation.

Risk factors are caused by processes, humans, systems and external factors. Process risk factor is caused by the absence of available procedures, ineffective monitoring, and inadequate coordination between units and mechanisms. Human risk factor can be caused by negligence in work, internal fraud, and inadequate competence and number of employees. System risk factor is caused by network communication errors, program errors, and viruses. In addition, external factors are caused by natural disasters, demonstrations and floods.

The risk management process has several stages which include: 1) risk identification by analyzing risk sources; 2) risk analysis by assessing the possible risks and arising risks; 3) plan of action by implementing further plans; and 4) control by measuring, controlling, supervising, and ensuring that management plans remain relevant (McNeil et. al., 2005).

\section{RESULTS AND DISCUSSION}

Risk management is the approach chosen to understand, identify, and evaluate risks in a project (Joni \& Putu, 2012). In addition, it pays attention to what must be carried out to the arising impact and the possibility of transferring risk to other parties or how to reduce the existing risks.

The objective of risk management is to recognize risks in a project and develop strategies to reduce or even avoid them. On the other hand, it also aims at how to find ways to maximize the existing opportunities.

To identify risks, it must answer questions about what is involved in risk and why? and what types of risks have an effect on the project?

Generally, the main sources of business risk are: 1) physical loss or damage due to fire, earthquake, flood, accident and landslide; 2) environment: ecological damage, pollution and waste treatment, and investigation of the condition of the society; 3) design: a new technology, new applications, tests, safety and security, details, greater risk of conformity specifications, designs arising from measurements and investigations, possible changes to agreed designs, and design interactions with construction methods; 4) logistics or material damage: loss of road equipment, special resources, and organizational separation; 5) finance: availability of funds and adequacy of insurance, provision of sufficient cash flows, losses caused by contractors, fluctuations in supplier exchange rates and inflation, taxes, interest rates, and loan costs; and 6) operation: market fluctuations for products and services, maintenance needs, reliability, safety, factory and management. 
Effective risk analysis must consider the following matters: 1) analysis must focus on direct financial loss rather than service disruption or death and loss; 2) uncertainty in each estimate of expenditure must be measurable; 3 ) the accuracy of the analysis must be based on data accuracy; and 3) costs and efforts for analysis must be as low as those that can be absorbed by the business budget (Tjakra \& Sangari, 2011).

The first is operational risk. Based on our research findings, the types of affecting risks are human resources, assets, information, technology and natural events. It includes: 1) the effect of human resources on risk caused by labors deliberately or accidentally which have a negative impact on the company; 2) the effect of assets on risk caused by damaged and improper equipment that is caused intentionally and unintentionally by the labors so that it has a negative impact on the company; 3) the effect of information technology on risks caused by damaged hardware and software that are done intentionally and unintentionally by labors that have a negative impact on the company; and 4) the effect of natural events on risks caused by natural conditions so that they have a negative impact on the company.

The second is marketing risk. Based on our research findings, the types of affecting risks are brand awareness that does not develop the risk of losing old customers, the risk of companies that do not develop a product, and an affordable market share. It includes: 1) the influence of brand awareness that does not develop caused by lack of marketing and introduction of the restaurants; 2) the risk of losing old customers because service to consumers is unsatisfactory; 3 ) the risk that the company does not develop that is caused by disproportionate amount of human growth based on the number of assets and brands that are not familiar to the public; and 4) an unreachable market share due to the lack of activeness in marketing the products.

The third is the human resource risk. Based on our research findings, the types of affecting risks are lack of costs, turnover, and human resources. It includes: 1) the effect of turnover due to lack of compensation given by the company; 2) lack of human resource costs due to the number of inappropriate employees; and 3) the shortage of human resource costs due to inappropriate analysis work (Hariandja, 2002).

The fourth is financial risk. Based on our research findings, the types of affecting risks are the risk of income leakage, the risk of cash calculation, liquidity management, and compliance with financial reporting. It includes 1) risk of income leakage due to limited product delivery, delays in lack of food orders, telephone numbers and so forth as a result of fraud and loss and risk of work control using transportation; 2) the risk of calculating cash due to errors in calculating cash requirements; 3) liquidity management due to late payment of debt flows; and 4) compliance with financial report due to delays in the presentation of financial statements that should be in accordance with the regulator's requirements.

Risks to human resources, assets, information technology and natural phenomena are caused by various things. Thus, employers need to master the arising risks. It includes: 1) the risk of human resources caused by workplace accidents, so, the risk control is the availability of stock of first aid drugs for work accidents, transportation to the emergency department, availability of work insurance, and building rehabilitation; 2) asset risk caused by damage to equipment, so, the risk control is to check all equipment periodically for approximately three months and plan to repair equipment damage and supply new equipment; 3) information technology risk caused by damage to hardware and software, so, the risk control is routine checking of hardware and software; and 4) the risk of natural phenomena caused by natural disasters, so, the risk control is to provide health insurance for employees. The following is the risk management in the business operations of a restaurant.

The risks include the brand awareness that does not develop the risk of losing old customers, the risk of the company that does not develop, and the unattainable target market caused by all kinds of things. Thus, employers need to master the arising risks. It includes: 1) brand awareness that does not develop caused by the lack of product marketing risks, so, the risk control is to introduce restaurants through social media; 2) the risk of losing old customers caused by unsatisfactory service to consumers, so, the risk control is listening to their complaints and evaluating the customer satisfaction on risk management; 3 ) the risk of the company that does not develop caused by the growth amount of the people that is not 
comparable to the number of assets and the brand is unfamiliar by the society, so the risk control is by introducing new products, improving machines, increasing employees and opening new restaurant branches; and 4) market share is unreachable caused by the lack of activeness in marketing products, so, the risk control is evaluating customer satisfaction.

Table 1 - Risk of Management

\begin{tabular}{|l|l|l|l|}
\hline Parameter & Risk & Cause & Control \\
\hline Human Resource & $\begin{array}{l}\text { Serious injuries, death, } \\
\text { disability }\end{array}$ & Work accident & $\begin{array}{l}\text { - First aid in accidents } \\
\text { - Emergency room } \\
\text { - Insurance } \\
\text { - Rehabilitation }\end{array}$ \\
\hline Asset & $\begin{array}{l}\text { The stoppage of the } \\
\text { production process }\end{array}$ & Damage to equipment & $\begin{array}{l}\text { - Periodical checking to the } \\
\text { equipment } \\
\text { - Improvement planning to the } \\
\text { damage equipment } \\
\text { - New equipment }\end{array}$ \\
\hline $\begin{array}{l}\text { Information } \\
\text { Technology }\end{array}$ & $\begin{array}{l}\text { Stranded at the operational } \\
\text { process }\end{array}$ & $\begin{array}{l}\text { Damage to hardware } \\
\text { and software }\end{array}$ & Routine checking \\
\hline $\begin{array}{l}\text { Nature } \\
\text { Phenomena }\end{array}$ & $\begin{array}{l}\text { Dysfunction, serious injuries, } \\
\text { death, disability }\end{array}$ & Natural disasters & Insurance \\
\hline
\end{tabular}

Table 2 - Risk of Marketing

\begin{tabular}{|l|l|l|l|}
\hline Parameter & Risk & Cause & Control \\
\hline $\begin{array}{l}\text { Brand awareness } \\
\text { that does not } \\
\text { develop }\end{array}$ & $\begin{array}{l}\text { Unfamiliar by } \\
\text { the public }\end{array}$ & $\begin{array}{l}\text { Lack of marketing and introducing } \\
\text { activities of the restaurant }\end{array}$ & $\begin{array}{l}\text { Introducing the restaurant through } \\
\text { social media }\end{array}$ \\
\hline $\begin{array}{l}\text { The risk of losing } \\
\text { old customers }\end{array}$ & $\begin{array}{l}\text { The sales } \\
\text { target is not } \\
\text { sufficient }\end{array}$ & $\begin{array}{l}\text { Unsatisfactory services to } \\
\text { customers }\end{array}$ & $\begin{array}{l}\text { Management complaint, } \\
\text { Evaluation to customer satisfaction }\end{array}$ \\
\hline $\begin{array}{l}\text { The risk of } \\
\text { company that does } \\
\text { not develop }\end{array}$ & $\begin{array}{l}\text { Result in a } \\
\text { loss for } \\
\text { company }\end{array}$ & $\begin{array}{l}\text { Brand company is unfamiliar by the } \\
\text { public, the number of people did not } \\
\text { growth in proportion to growth asset }\end{array}$ & $\begin{array}{l}\text { Introducing new products, } \\
\text { upgrading the machine, improving } \\
\text { the employees, and opening } \\
\text { restaurant branch }\end{array}$ \\
\hline $\begin{array}{l}\text { The unattainable } \\
\text { target market }\end{array}$ & Loss charter & $\begin{array}{l}\text { The marketing activity is less active } \\
\text { in offering and promoting the } \\
\text { products }\end{array}$ & Evaluating customer satisfaction \\
\hline
\end{tabular}

The risks include lack of costs, turnover, and human resources caused by all kinds of things. Thus, employers need to master the arising risks. It includes: 1) the effect of turnover caused by the lack of compensation provided by the company, so, the risk control is the provision of annual bonuses and awards to outstanding employees; 2) lack of human resource caused by inappropriate numbers of employees, so, the risk control is to evaluate workload and employee capacity; and 3) lack of human resource costs caused by inappropriate job analysis, so, the risk control is the evaluation on employees' work.

Table 3 - Risk of Human Resource

\begin{tabular}{|l|l|l|l|}
\hline Parameter & Risk & Cause & Control \\
\hline Turnover & $\begin{array}{l}\text { The high level of } \\
\text { turnover }\end{array}$ & $\begin{array}{l}\text { Lack of compensation given } \\
\text { by a company }\end{array}$ & $\begin{array}{l}\text { Giving an annual bonus and } \\
\text { rewards for outstanding employees }\end{array}$ \\
\hline $\begin{array}{l}\text { Human } \\
\text { resource }\end{array}$ & $\begin{array}{l}\text { Inappropriate number } \\
\text { of employees }\end{array}$ & $\begin{array}{l}\text { Calculation the number of } \\
\text { needs to employees }\end{array}$ & $\begin{array}{l}\text { Conduct an evaluation workload } \\
\text { and capacity of employees }\end{array}$ \\
\hline $\begin{array}{l}\text { Human } \\
\text { resource costs }\end{array}$ & Job analysis & Inappropriate job analysis & Evaluation on employees' work \\
\hline
\end{tabular}

The risks include income leakage, cash calculation, liquidity management and compliance with financial reporting caused by all kinds of things. Thus, employers need to master the arising risks. It includes: 1) income leakage caused by limited distance in product delivery, delays in ordering the lack of food, unlinked telephone numbers, and the result of fraud and loss, so risk control is working with online transportation, providing a fleet of 
vehicles according to the projected number of consumers, providing online chat facilities to increase the number of telephone numbers, increase labor, guarantee operational standards and procedures, and use a sales system; 2) liquidity management for late payment of debt caused by errors in cash calculations, so risk control is to pay attention to future cash flows of income and purchases, 3) management of liquidity mainly due to late payments from debt flows, so risk control is analyzing financial statements and determine the closing time of financial statements.

Table 4 - Risk of Financial

\begin{tabular}{|l|l|l|l|}
\hline Parameter & Risk & Cause & Control \\
\hline Income leakage & Limited distance in product delivery & $\begin{array}{l}\text { Lack of vehicles delivery } \\
\text { and difficulties in } \\
\text { maintaining the quality of } \\
\text { far journey }\end{array}$ & Using online transportation \\
\cline { 2 - 4 } & delays in ordering the lack of food & $\begin{array}{l}\text { The far distance of food } \\
\text { delivery }\end{array}$ & $\begin{array}{l}\text { Providing transportation in } \\
\text { accordance with projection } \\
\text { of the number of customers }\end{array}$ \\
\cline { 2 - 5 } & $\begin{array}{l}\text { Unlinked customers' telephone } \\
\text { numbers }\end{array}$ & A lack of telephone & $\begin{array}{l}\text { Providing online chat } \\
\text { facility }\end{array}$ \\
\cline { 2 - 5 } & Losses from fraud & $\begin{array}{l}\text { Lack of employee } \\
\text { supervision }\end{array}$ & $\begin{array}{l}\text { Ensuring that employees } \\
\text { adhering to a standard } \\
\text { operating procedure } \\
\text { properly }\end{array}$ \\
\hline $\begin{array}{l}\text { Cash } \\
\text { calculation }\end{array}$ & $\begin{array}{l}\text { Inability in meeting the needs of } \\
\text { exact cash flow }\end{array}$ & $\begin{array}{l}\text { A mistake in cash } \\
\text { requirement calculation }\end{array}$ & $\begin{array}{l}\text { Taking into account the } \\
\text { income and expenditure of } \\
\text { the cash flow in the future }\end{array}$ \\
\hline $\begin{array}{l}\text { Liquidity } \\
\text { management }\end{array}$ & $\begin{array}{l}\text { Loss or the appearance of the likely } \\
\text { cost resulting from the failure of } \\
\text { counter-parties payment }\end{array}$ & $\begin{array}{l}\text { Delays in the payment of } \\
\text { current debt }\end{array}$ & $\begin{array}{l}\text { Ensuring sufficient cash } \\
\text { balance for the payment of } \\
\text { current debt }\end{array}$ \\
\hline $\begin{array}{l}\text { Adherence to } \\
\text { financial report }\end{array}$ & $\begin{array}{l}\text { Failure to comply with the } \\
\text { international, national, and local } \\
\text { law and regulations that are } \\
\text { associated with the business } \\
\text { process }\end{array}$ & $\begin{array}{l}\text { The delay in the } \\
\text { presentation of the } \\
\text { financial statements }\end{array}$ & $\begin{array}{l}\text { Adherence to financial } \\
\text { report }\end{array}$ \\
\hline
\end{tabular}

\section{CONCLUSION}

For each project, risk management is very essential to avoid loss of project costs, quality and schedule. Risk management is an approach chosen toward the risks by understanding, identifying and evaluating the risks of a project. It is carried out by paying attention to what must be conducted to the consequences and the possibility of transferring risk to other parties or by reducing the occurring risks. Risk assessment includes: identifying risk, understanding needs or considering risks, analyzing the impact of risks or evaluating risks, and those responsible for certain risks. Handling the possible risks may be carried out by risk retention, risk reduction, risk transfer, and risk avoidance.

\section{REFERENCES}

1. Fred, R D. 2011. Strategic Management. Jakarta: Salemba Empat.

2. Hariandja, M. T. E. (2002). Manajemen sumber daya manusia. Jakarta: Grasindo.

3. Joni, I., \& Putu, G. (2012). Resiko Manajemen Proyek. Jurnal Ilmiah Teknik Sipil Vol, 16(1).

4. Labombang. 2011. Manajemen Risiko Dalam Proyek Kontruksi. Palu: Jurnal SMARTek Vol. 9 No. 1.

5. Leonardus, S. 2009. Kewirausahan Teori, Praktik, dan Kasus-kasus. Jakarta: Salemba Empat.

6. Lokobal, A., Sumajouw, M. D., \& Sompie, B. F. (2014). Manajemen Risiko Pada Perusahaan Jasa Pelaksana Konstruksi Di Propinsi Papua (Study Kasus Di Kabupaten Sarmi). Jurnal IImiah Media Engineering, 4(2). 
7. McNeil, A. J., Frey, R., \& Embrechts, P. (2005). Quantitative risk management: Concepts, techniques and tools (Vol. 3). Princeton: Princeton university press.

8. Nasution, A. H., \& Prasetyawan, Y. (2003). Perencanaan dan pengendalian produksi. Surabaya: Guna Widya.

9. Oswari, T., \& Suhendra, E. S. (2013). Proyeksi Manajemen Risiko Operasional Pembukaan Kantor Cabang Perusahaan Asuransi di Indonesia. Jurnal Asuransi dan Manajemen Risiko, 1(2).

10. Sandyavitri, A. (2009). Manajemen Resiko di Proyek Konstruksi. Media Komunikasi Teknik Sipil, 17(1), 23-38.

11. Sensebé, L., Bourin, P., \& Tarte, K. (2010). Good manufacturing practices production of mesenchymal stem/stromal cells. Human gene therapy, 22(1), 19-26.

12. Tjakra, J., \& Sangari, F. (2011). Analisis Resiko Pada Proyek Konstruksi Perumahan Di Kota Manado. Jurnal IImiah Media Engineering, 1(1). 